\title{
日本循環器学会指定 循環器研修施設
}

\section{北海道地区}

北海道大学医学部附属病院

札㹸医科大学医学部附属総合病院

旭川医科大学医学部附属病院

社会福祉法人函館厚生院函館中央病院

市立室蘭総合病院

医療法人王子総合病院

医療法人社団延山会北成病院

国家公務員等共済組合連斗南病院

厚生連総合病院带広厚生病院

市立釧路総合病院

国立札棂病院

社会福祉法人函館厚生院函館五稜郭病院

医療法人社団札幌循環器クリニック

NTT 札幌病院

医療法人碩心会北海道大野病院

北光循環器病院

市立旭川病院

総合病院旭川赤十字病院

手稲溪仁会病院

函館市医師会病院

医療法人社団新日鐵室蘭総合病院

医療法人社団北海道恵愛会南一条病院

市立函館病院

国立函館病院

市立札棍病院

砂川市立病院

札幌社会保険総合病院

札幌鉄道病院

釧路市医師会病院

医療法人財団敬和会時計台病院

聖母会天使病院

札幌東徳洲会病院

北海道社会事業協会带広病院

市立士別総合病院

\section{東 北地区}

福島県立医科大学附属病院

財団法人星総合病院

東北大学医学部附属病院

労働福祉事業団東北労災病院

仙台循環器病センター

山形大学医学部附属病院

山形市立病院済生館

秋田大学医学部附属病院

秋田県成人病医療センター

平鹿総合病院

岩手医科大学附属病院

岩手県立中央病院

弘前大学医学部付属病院

医療法人明和会中通総合病院

岩手県立胆沢病院

青森県立中央病院

いわき市立総合磐城共立病院

仙台市医療センター仙台オープン病院

財団法人宮城厚生協会坂総合病院

山形県立中央病院

秋田県立脳血管研究センター

秋田組合総合病院

財団法人竹田綜合病院

労働福祉事業団福島学贸病院
仙台市立病院

仙台德洲会病院

国立仙台病院

米沢市立病院

財太田綜合病院附属太田西/内病院

仙台社会保険病院

小白川至誠堂病院

社会福祉法人恩賜財団北上済生会病院

八戸市立市民病院

䀧大原綜合病院附属大原医療セン夕一 東北厚生年金病院

公立学校共済組合東北中央病院

鶴岡市立荘内病院

秋田赤十字病院

岩手労災病院

済生会福島総合病院

(財)脳神経疾患研究所附属南東北病院

特定医療法人明精会会津西病院

山形県立新庄病院

山形県立日本海病院

\section{関東甲信越地区}

東京大学医学部附属病院

東京医科歯科大学附属病院

東京医科歯科大学難治疾患研究所

東京慈恵会医科大学附属病院

東京慈恵会医科大学附属青戸病院

日本医科大学附属病院

日本医科大学付属多摩永山病院

順天堂大学医学部附属順天堂医院

慶應義塾大学病院

東京女子医科大学病院

東京女子医科大学成人医学センター

東京女子医科大学附属第二病院

東京医科大学病院

東京医科大学八王子医療センター 昭和大学病院

東邦大学医学部付属大橋病院

東邦大学医学部付属大森病院

日本大学医学部附属板橋病院

駿河台日本大学病院

帝京大学医学部附属病院

杏林大学医学部付属病院

社会福祉法人三井記念病院

東京警察病院循環器センター

東京逓信病院

国家公務員等共済組合連虎の門病院

財)心臓血管研究所付属病院

東京都済生会中央病院

東京都立駒込病院

関東聥信病院

東京都立広尾病院

榊原記念病院

国立東京第二病院

東京共済病院

公立学校共済組合関東中央病院

国立国際医療センター

東京厚生年金病院

東京都老人医療センター

武蔵野赤十字病院

総合病院立川相互病院

聖マリアン十医科大学附属病院
聖マリアン十医科大学横浜市西部病院

横浜市立大学医学部附属瘁院

昭和大学藤が丘病院

北里大学病院

東海大学医学部付属病院

労働福祉事業団関東労災病院

国家公務員等共済組合連横浜栄共済病院

藤沢市民病院

千葉大学医学部附属病院

帝京大学医学部附属市原病院

船橋市立医療センター

千葉県勤労者医療協会船橋二和病院

医療法人社団保健会谷津保健病院

千葉社会保険病院

千葉県勤労者医療協会千葉健生病院

筑波大学附属病院

土浦協同病院

獨協医科大学病院

自治医科大学附属病院

獨協医科大学越谷病院

埼玉医科大学総合医療センター

防衛医科大学校病院

大宮赤十字病院

医療法人財団石心会狭山病院

群馬大学医学部附属病院

国立高崎病院

群馬県立循環器病センター

医療法人北関東循環器病院

信州大学医学部附属病院

長野赤十字病院

長野県厚生連北信総合病院

山梨医科大学医学部附属病院

新潟大学医学部附属病院

綜合病院長岡赤十字病院

医療法人博医会新潟こばり病院

東京都教職員互助会三楽病院

聖路加国際病院

東京大学附属病院分院

JR 東京総合病院

公立昭和病院

東京慈恵会医科大学附属第三病院

神奈川県立循環器呼吸器病センター

国立横浜病院

湘南鎌倉総合病院

横須賀市立市民病院

千葉市立海浜病院

東京慈恵会医科大学附属柏病院

東京医科大学霞分浦病院

柘木県済生会宁都宮病院

足利赤十字病院

自治医科大学附属大宮医療センター 濒市立病院

埼玉医科大学附属病院

山梨県立中央病院

(社)山梨勤労者医療協会甲府共立病院

新潟市民病院

東京労災病院

財団法人日産厚生会玉川病院

けいゆう病院

総合病院国保旭中央病院

労働福祉事業団千葉労災病院

千葉県立鶴舞病院 
刍田総合病院

社会福祉法人水戸済生会総合病院

浦和市立病院

群馬県済生会前橋病院

医療法人立川綜合病院

済生会新潟第二病院

東京女子医科大学附属青山病院

総合病院厚生中央病院

白衛隊中央病院

日本大学医学部附属練馬光が丘病院

横浜労災病院

横浜赤十字病院

国家公務員等共済組合連横浜南共済病院 総合病院横須賀共済病院

国際親善総合病院

茅ケ崎市立病院

千葉西総合病院

国保八日市場市民総合病院

総合病院取手協同病院

医療法人社団東光会戸田中央総合病院

小川赤十字病院

新潟県立新発田病院

日本赤十字社東京都支部大森赤十字病院

医療法人財団石心会川㥓幸病院

医療法人緑成会横浜総合病院

神奈川県厚生農協連相模原協问病院

済生会横浜市南部病院

国立横浜東病院

平塚市民病院

国立療養所神奈川病院

国保松戸市立病院

医療法人社団三記東鳳新東京病院

順天堂大学医学部附属順天堂浦安病院

東邦大学医学部付属佐合病院

筑波記念病院

筑波メディカルセンター病院

国立埼玉病院

深谷赤十字病院

新潟県立中央病院

医療法人桑名恵風会桑名病院

信楽園病院

新潟県立がんセンタ一新潟病院

葛西循環器脳神経外科病院

社会保険中央総合病院

日本鋼管病院

医療法人横浜博萌会西横浜国際総合病院

日本医科大学付属千葉北総病院

株日立製作所日立総合病院

川口市立医療センター

埼玉県済生会栗橋病院

埼玉県立小原循環器病センター

松本協立病院

甲低城南病院

社会保険山梨病院

山梨赤十字病院

財団法人山梨厙生会!梨厚生病院

木戸病院

東京都保健医療公社東部地域病院

東京都立荏原病院

日本赤十字社医療センター

東京都職員共済組合青山病院

東京都立府中病院

東京都多摩老人医療センター

勛)東京都保健医療公社多摩南部地域病院

川崎市立川㱦病院

横浜市立大学医学部附属浦舟病院

医療法人沖繩徳洲会千葉德洲会病院

医療法人社団全仁会宇都宮中央病院

宇都宮社会保険病院
済生会川口総合病院

多野総合病院

JA 長野厚生連小諸厚生総合病院

新潟県厚生連中央綜合病院

新潟県立六日町病院

労動福祉事業団燕労災病院

東 海 地 区

名吉屋大学㗨学部附属病院

名古屋大学環境医学研究所

名古屋市立大学病院

藤田保健衛生大学病院

愛知医科大学附属病院

豊橋市民病院

愛知県厚生農業協同組合連更生病院

邚谷総合病院

名鉄病院

社会保険中景病院

名古屋市立緑市民病院

国立名古屋病院

国家公務員等共済組合連名城病院

名古屋第二赤十字病院

愛知県厚生農業協同組合連加茂病院 小牧市民病院

浜松医科大学医学部附属病院

総合病院聖隷浜松病院

掛川市立総合病院

岐阜大学医学部附属病院

岐阜県立岐阜病院

岐皁市民病院

国立療養所岐阜病院

羽島市民病院

大垣市民病院

三重大学医学部附属病院

三重県立総合医療センター

山本総合病院

三重県厚生連鈴鹿中央総合病院

医療法人永井病院

重県厚生連松阪中央総合病院

済生会松阪総合病院

名古屋第一赤十字病院

名古屋掖済会病院

労働福祉事業団中部労災病院

協立総合病院

医療法人和伸会和田内科病院

春日井市民病院

愛知県立尾張病院

松波総合病院

岐皁赤十字病院

岐阜県立多治見病院

土岐市立総合病院

医療法人同心会遠山病院

山田赤十字病院

市立伊勢総合病院

上野総合市民病院

国立東静病院

静岡県立総合病院

静岡済生会総合病院

静㒺市立静阙病院

市立島田市民病院

聖隷三方原病院

袋井市立袋井市民病院

磐田市立綕合病院

愛知県厚生農業協同組合連渥美病院

西尾市民病院

トヨ夕記念病院

国立療養所中部病院

半田市立半田病院

宮市立市民病院
岐阜県厚生連撮斐総合病院

岐阜県厚生連岐北総合病院

市立四日市病院

松阪市民病院

尾敦総合病院

藤枝古立総合病院

労㗢福祉事業団浜松労災病院

県西部浜松医療センター

宏潤会六同病院

総合病院南生協病院

愛知県厚生連昭和病院

医療法人厚生会木沢記念病院

国立津病院

社会保隃桜ケ丘総合病院

公立陶生病院

愛知県厚生農業協同組合連海南病院

朝日大学篓学部附属村上記念病院

医療法人社団誠広会平野総合病院

蒲郡市民病院

市立岡崎病院

常滑市民病院

旭労災病院

中日病院

医療法人社団慈明会澤田病院

医療法人慶晆会千手堂病院

朝日大学歯学部附属病院

公立学校共済組合東海中央病院

平田病院

北陸 地 区

福井医科大学医学部附属病院

福井県立病院

福井循環器病院

金沢大学医学部附属病院

金沢医科大学病院

石川県立中央病院

国家公務員等共済組合連北陸病院

富山医科薬科大学附属病院

富山市立富山市民病院

高岡市民病院

富山県立中央病院

富山赤十字病院

厚生連高岡病院

金沢循環器病院

公立能登総合病院

黑部市民病院

市立砥波総合病院

福井県済生会病院

国立金沢病院

国民健康保険小松市民病院

金沢市立病院

近 畿 地 区

大阪大学医学部附属病院

大阪市立大学医学部附属病院

大阪医科大学附属病院

関西医科大学病院

近畿大学医学部附属病院

国立循環器病センター-

大阪府済生会中津病院

財田附興風会北野病院

住友病院

医療法人渡辺医学会桜橋渡辺病院

大阪府立成人病センター

大阪鉄道病院

大阪府立病院

大阪府三島救命救急センター

松下記念病院

八尾市立病院 
医療法人宝生会 PL 病院

国立大阪南病院

医療法人同仁会耳原総合病院

大阪労災病院

国立療養所千石荘病院

京都大学医学部附属病院

京都府立医科大学附属病院

京都第二赤十字病院

社会福社法人京都社会事業財団西陣病院

京都第一赤十字病院

三菱京都病院

滋賀医科大学医学部附属病院

大津赤十字病院

滋賀県立成人病センター

長浜赤十字病院

国立八日市病院

奈良県立医科大学附属病院

国立奈良病院

奈良県立奈良病院

榛原町立榛原総合病院

奈良県立三室病院

和歌山県立医科大学附属病院

神戸大学医学部附属病院

兵庫医科大学病院

神戸掖済会病院

医療法人昭生病院

済生会兵庫県病院

労働福祉事業団神戸労災病院

社会保険神戸中央病院

鐘紡記念病院

国立神戸病院

兵庫県立淡路病院

国家公務員等共済組合連六甲病院

兵庫県立尼崎病院

公立学校共済組合近畿中央病院

宝塚市立病院

兵庫県立姫路循環器病センター

国立姫路病院

兵庫県立成人病センター

国立明石病院

三木市立三木市民病院

市立加西病院

大津市民病院

大阪回生病院

淀川キリスト教病院

国立大阪病院

大阪赤十字病院

大阪警察病院

(財)日本生命済生会附属日生病院

関西電力病院

大阪厚生年金病院

社会福祉法人大阪暁明館病院

医療法人愛仁会干船病院

医療法人三世会河内総合病院

市立堺病院

清恵会病院

馬場記念病院

医療法人生長会ベルランド総合病院

社会保険京都病院

国立京都病院

社会福祉法人済生会京都府病院

日本赤十字社和歌山医療センター

神鋼病院

三菱神戸病院

財団法人甲南病院

労働福祉事業団関西労災病院

三田市民病院

兵庫県立柏原病院

公立豊岡病院組合立日高病院
新日本製鐵広畑製鐵所病院

神鋼加古川病院

市立小野市民病院

赤穂市民病院

国家公務員等共済組合連大手前病院

大阪船員保険病院

総合病院南大阪病院

医療法人仙養会北捸病院

高焚赤十字病院

医療法人若弘会若草第一病院

国立療養所近畿中央病院

和泉市立病院

武田病院

医療法人医仁会武田総合病院

京都府立医大附属小児䛈患研究施設

洛和会音羽病院

京都桂病院

国家公務員等共済組合連舞鶴共済病院

財団法人天理よろづ相談所病院

国立療養所和歌山病院

社会保险紀南綜合病院

有田市立病院

医療法人浩生会舞子台病院

北大阪病院

医療法人愛仁会高槻病院

星ケ丘厙生年金病院

市立枚方市民病院

東大阪市立中央病院

医真会八尾病院

市立柏原病院

岸和田市立岸和田市民病院

向陽病院

国立南和歌山病院

神戸市立中央市民病院

国立篠山病院

大阪市立総合医療センター

大阪府済生会野江病院

医療法人きこj会総合病院多根病院

千里保健医療センタ一新干里病院

京都市立病院

京都府立洛東病院

医療法人岡本病院第二岡本総合病院

医療法人康仁会西の京病院

海南市民病院

医療法人社団健心会北都病院

医療法人明和病院

市立伊丹病院

近江八幡市民病院

市立長浜病院

市立豊中病院

関西医科大学附属香里病院

大阪府立羽电野病院

大阪府立母子保健総合医療センター

医療法人生長会府中病院

市立貝塚病院

綾部市立病院

財団法人甲南病院六甲アイランド病院

高明会西宮渡辺病院

公立豊岡病院

社会保険滋賀病院

市立泉佐野病院

公立南丹病院

誠佑記念病院

医療法人社団幸泉会高田外科病院

医療法人回生会宝塚病院

\section{中 国 地 区}

鳥取大学医学部附属病院

島根医科大学医学部附属病院
島根県立中央病院

岡山大学医学部附属病院

川崎医科大学附属病院

心臓病センター榊原病院

総合病院岡山赤十字病院

国立岡山病院

広島大学医学部附属病院

国立福山病院

福山市市民病院

社会保険広島市民病院

国家公務員等共済組合連只共済病院

山口大学医学部附属病院

山口県立中央病院

下関市立中央病院

済生会下関総合病院

総合病院松江赤十字病院

松江市立病院

財団法人倉敷中央病院

県立広島病院

国立呉病院

労働福祉事業団中国労贸病院

広島県厚生連広島総合病院

国立岩国病院

国立下関病院

済生会山口総合病院

宇部興産中央病院

医療法人厚南セントヒル病院

医療法人あか子会土谷総合病院

総合病院松江生協病院

広島市立安佐市民病院

綜合病院社会保険徳山中央病院

医療法人神德会三田尻病院

医療法人財団竹政会福山循環器病院

総合病院光市立病院

山口県厚生農業協同組合連長門総合病院

鳥取県立厚生病院

広島赤十字原爆病院

済生会広島病院

医療法人社団成蹊会岡田病院

四 国 地 区

香川医科大学医学部附属病院

高松赤十字病院

国立善通寺病院

三豊総合病院

德島大学医学部附属病院

国立療養所東德島病院

高知医科大学附属病院

高知市立市民病院

愛媛大学医学部附属病院

愛媛県立中央病院

松山赤早字病院

国立療養所愛媛病院

愛媛県立新居浜病院

愛媛県立今治病院

香川県立中央病院

小松島赤十字病院

喜多医師会病院

市立宇和島病院

徳島県立中央病院

阿南医師会中央病院

徳島厚生農協連総合病院麻植協同病院 市立八幡浜総合病院

宇和島社会保険病院

香川県立白鳥病院

西条中央病院

社会福祉法人恩賜財団済生会今治病院 近森病院

済生会西条病院 
瀬戸内海病院

\section{九 州 地 区}

九州大学医学部附属病院

福岡大学病院

産業医科大学病院

久留米大学病院

九州厚生年金病院

福岡市立こども病院·感染症センター

国家公務員等共済組合連浜の町病院

国家公務員等共済組合連千早病院

福阙市医師会成人病センター

麻生セメント株式会社飯塚病院

医療法人天神会古賀病院

佐賀医科大学附属病院

長崎大学医学部附属病院

熊本大学医学部附属病院

済生会熊本病院

国家公務員等共済組合連熊本中央病院

大分医科大学医学部附属病院

宮崎医科大学医学部附属病院

鹿児島大学㗨学部附属病院

国立南九州中央病院

琉球大学医学部附属病院
社会保険小倉記念病院

福岡県済生会福岡総合病院

国家公務員等共済組合連合会新別府病院

九州大学生体防御医学研究所附属病院

沖繩協同病院

石原内科循環器科满院

雪の聖母会聖マリア病院

佐賀県立病院好生館

医療法人光晴会病院

熊本赤十字病院

公立玉名中央病院

医療法人天陽会中央病院

医療法人社団誠心会萩原中央病院

福岡県立遠賀病院

医療法人原三信病院

福岡大学筑紫病院

労働福祉事業団筑豊労災病院

長崎市立市民病院

日本赤十字社長崎原爆病院

医療法人宏善会高橋病院

国立長崎中央病院

佐世保市立総合病院

熊本市立熊本市民病院

国立別府病院
那覇市立病院

沖繩県立中部病院

国立病院九州医療センター

北九州市立医療センター

国立小倉病院

医療法人弘恵会ヨコクラ病院

労働福祉事業団長崎労災病院

長崎県立成人病センター多良見病院

総合病院鹿悲島生拹病院

新日本製鐵株式會社八幡製鐵所病院

医療法人白十字会白十字病院

久留米大学医学部附属医療センター

医療法人親仁会米の山病院

国立能本病院

医療法人仁愛会浦添総合病院

労働福禅事業団門司労災病院

国立療養所福岡東病院

総合病院千鳥橋病院

福岡赤十字病院

新杏病院

鹿児島市医師会病院

鹿児島市立病院

社団法人鹿児島共済会南風病院

(合計 653施設)

(1996年11月20日現在）

\section{日本循環器学会指定 循環器研修関連施設}

\section{北海道地 区}

医療法人社団日鋼記念病院

国立療養所西札幌病院

名寄市立総合病院

北海道社会事業協会小樽病院

厚生連総合病院加川厚生病院

厚生年金事業振興団登別厚生年金病院 美唄労災病院

木原循環器科内科医院

北海道立北見病院

札幌德洲会病院

国家公務員等共済組合連合会幌南病院

医療法人北海道循環器病院

岩見沢労災病院

総合病院伊達赤十字病院

栗山赤十字病院

留萌市立総合病院

\section{東 北 地 区}

岩手県立江刺病院

総合病院仙台赤十字病院

市立酒田病院

医療法人辰星会枅記念病院

東北大学加齢医学研究所附属病院

財団法人三友堂病院

白河厚生総合病院

総合保原中央病院

医療法人平心会須賀川病院

原町市立病院

石巻赤十字病院

本荘第一病院

盛岡赤十字病院

医療法人西城病院
福島南循環器科病院

(財)湯浅報恩会寿泉堂綜合病院

南陽市立総合病院

市立秋田総合病院

釜石市民病院

十和田市立中央病院

\section{関東甲信越地区}

(財)朝日生命成人病研究所附属病院

国家公務員等共済組合連合会立川病院 川崎市立井田病院

川崎製鉄健康保険組合千葉病院

財団法人筑波学園病院

医療法人貞心会西山堂病院

埼玉協同病院

医療法人知命堂病院

新潟県厚生農協組合連刈羽郡総合病院

白根健生病院

佐渡厚生連佐渡総合病院

新潟県厚生連村上総合病院

新潟県立吉田病院

至誠會第二病院

立正佼成会附属佼成病院

医療法人社団明芳会板橋中央総合病院 板橋区医師会病院

公立阿伎留病院

東芝林間病院

国立横須賀病院

国立療羔所晴嵐荘病院

大田原赤十字病院

諏訪共立病院

医療法人嵐陽会三之町病院

千葉県救急医療センター

東京健生病院
西新井病院

医療法人社団慈敬会府中医王病院 三菱重工大倉山病院

菊名記念病院

横浜市立港湾病院

聖テレジア病院

城南病院

春日部市立病院

社団法人東松山医師会病院

社団法人伊勢崎佐波医師会病院

長野医療生活協同組合長野中央病院

長野県厚生連佐久総合病院

長野県厚生連篠/井総合病院

組合立諏訪中央病院

讘訪赤十字病院

見附市立成人病センタ一病院

東名厚木病院

東松山市立市民病院

佐々木研究所附属杏雲堂病院

東京都立大久保病院

医療法人財団荻寉病院

東京都国民健康保険団体連合会福生病院

青梅市立総合病院

医療法人財団大和会東大和病院

国立千葉病院

柏市立柏病院

国立霞ケ浦病院

つくば双愛病院

上都賀総合病院

国立松本病院

国立病院東京災害医療センター

博慈会記念総合病院

国立相模原病院

国家公務員等共済組合連平塚共済病院 